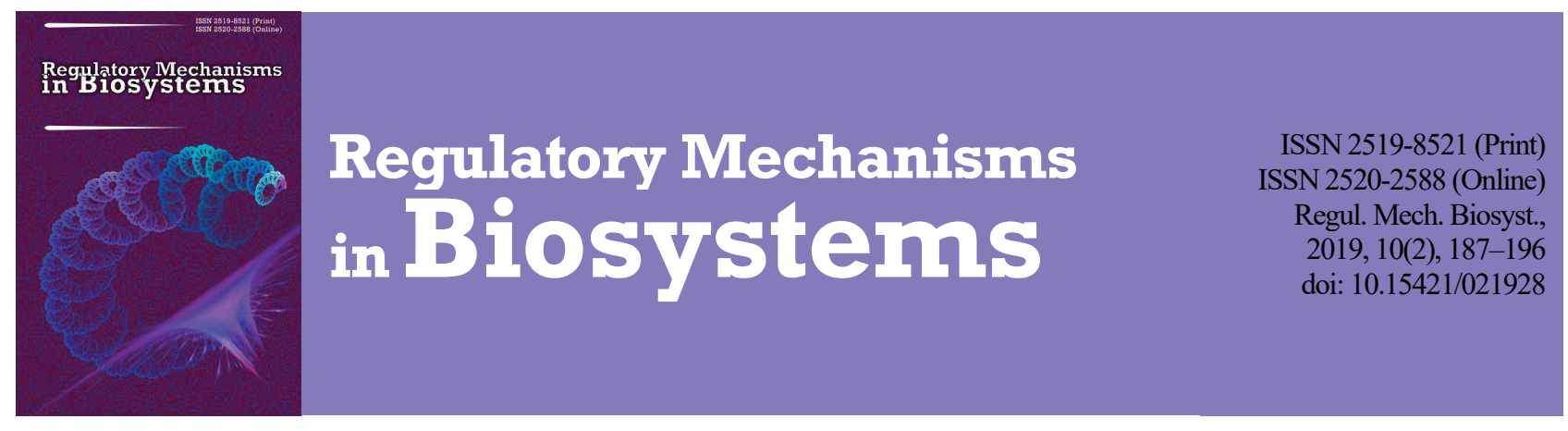

\title{
In vitro effects of platelet-derived factors of brain glioma patients on C6 glioma cells
}

\author{
L. D. Liubich, N. I. Lisyanyi, T. A. Malysheva, L. P. Staino, D. M. Egorova, V. V. Vaslovych \\ State Institution "Romodanov Neurosurgery Institute, National Academy of Medical Sciences of Ukraine”, Kyiv, Ukraine
}

\author{
Article info \\ Received 28.03.2019 \\ Received in revised form \\ 21.04.2019 \\ Accepted 25.04.2019
}

State Institution "Romodanov

Neurosurgery Institute,

National Academy

of Medical Sciences

of Ukraine",

Platona Mayborodyst., 32,

Kyiv, 04050, Ukraine.

Tel.: +38-044-483-92-08.

E-mail:

lyubichld@gmail.com

\begin{abstract}
Liubich, L. D., Lisyanyi, N. I., Malysheva, T. A., Staino, L. P., Egorova, D. M., \& Vaslovych, V. V. (2019). In vitro effects of platelet-derived factors of brain glioma patients on C6 glioma cells. Regulatory Mechanisms in Biosystems, 10(2), 187-196. doi:10.15421/021928
\end{abstract}

Platelets play an important part in the progression and pathological angiogenesis of brain glioma because of the different granules content and release of microvesicles that are the source of numerous mediators and bioactive substances, which probably provides a "strategy" for the tumour survival. The objective of study was exploring the effect of platelet-released secretion products of patients with brain glioma on the experimental model of tumour growth in vitro. For this purpose, the cells of glioma C6 were cultured for 72 hours under the addition of modified media containing platelet-released secretion products or conditioned media of peripheral blood cells of patients with glioma as well as persons of the comparison group without rough somatic pathology. In control glioma C6 cultures in standard conditions cell clusters were formed by the type of "spheroids", from which radial cell migration occurred, a tense cellular or reticular growth zone was formed, and tumour cells preserved their ability to mitotic division. Under the influence of platelet-released secretion products of patients with glioma, differently directed effects on cell mitotic activity and the number of cell clusters in glioma $\mathrm{C} 6$ cultures were detected depending on the degree of tumour malignancy: stimulating effect under the influence of platelet factors of patients with high-malignancy glioma (G4) and inhibitory effect - due to the influence of platelet factors of patients with differentiated glioma (G2). In contrast to the thrombocyte-released factors, the conditioned media of a common pool of peripheral blood cells of patients with G4 glioma suppressed the mitotic activity of tumour cells and did not affect the number of cell clusters. No changes in glioma C6 cultures were revealed after the influence of platelet-released secretion products of persons of the comparison group. The obtained data confirm the important role of platelets in the pathogenesis of brain glioma, pointing to the fundamental difference in the spectrum of biologically active molecules that are released by platelets of patients depending on the degree of tumour malignancy and are able to regulate the cell cycle and proliferative activity of the glioma tumour cells, which may have application as a diagnostic marker as well as predictive marker of response to antitumour therapy.

Keywords: thrombocytes; released secretion products; conditioned medium; tumour cells; mitotic index; cell clusters.

\section{Introduction}

Despite careful studies of the causes and mechanisms of the glial tumour progression around the world, today no significant clinical progress in their treatment has been achieved due to the invasive spread and multiresistance to adjuvant therapy methods. The current incidence of malignant variants of primary brain tumours in Ukraine, by the last National Cancer Registry data, is 5.2 per 100 thousand of population, and mortality - 3.8 (Fedorenko et al., 2019). Among the primary tumours of the central nervous system, malignant forms of glioma predominate. The combination of surgery, radiation and chemotherapy is a gold standard in the complex treatment of these tumours, but does not provide the desired efficacy. In this context, the active search for alternative methods of treatment of this type of CNS pathology continues.

There is an urgent need for creation of new cell-molecular technologies for diagnosis and therapeutic effects on brain tumours. In particular, at the present stage of fundamental research, the tools for targeted therapy for malignant brain glioma and long-term antitumour response induction by adjusting the immune system are being explored. Stem cells (neurogenic stem/progenitor cells (NSC/NPCs), mesenchymal stem cells) application opportunities as biological delivery vehicles of various ligands - cytolytic viruses, genes encoding cytokines (IL-4, IL-12, IL-2, IL-23, GM-CSF, IFN- $\beta$ ), proapoptotic genes (TRAIL, FASL), enzymes that convert pharmaceutical agents into the active form (cytosine deaminase, thymidine kinase), neurotrophic factors, are being studied (Portnow et al., 2017; Mooney et al., 2018; Gutova et al., 2019; Li et al.,
2019). Other actively developing directions are adoptive immunotherapy with effector immune cells (T-, NK-cells) and different approaches to increasing their functionality: immunological checkpoint blockade with monoclonal antibodies; bispecific antibodies against both tumour antigens and immune cells; genetically engineered cells with chimeric antigen receptors (CARs); systemic administration of cytokines or priming immune cells to strengthen tumour killing and homing function (Poggi \& Giuliany, 2016; Veluchamy et al., 2017; Matosevic, 2018).

Recently, special attention has been drawn to the factors of inflammation and natural immunity, due to their pathogenetic role in the tumour process and tumour microenvironment-induced reprogramming of effector cells (Kaya et al., 2017; Chambers et al., 2018). In particular, attention is focused on evaluation of prognostic significance of the proportion of major cell populations in peripheral blood of patients: quantitative ratios of neutrophil-to-lymphocyte, platelet-to-lymphocyte, monocyte-to-lymphocyte (van Linde et al., 2016; Bao et al., 2018; Lopes et al., 2018; Saito et al., 2018). A high platelet-to-lymphocyte ratio in the preoperative period is predictive of a poor prognosis for glioma patients (Bao et al., 2018) and reduced rates of platelets correlate with overall survival (Saito et al., 2018). Platelets are considered as noninvasive biomarkers for malignant glioma and treatment response evaluation (Best et al., 2018).

Platelets, also called thrombocytes, are derivatives of bone marrow megakaryocytes - namely, fragments of their cytoplasm, and have no cell nucleus (Machlus et al., 2014). In conditions of physiological norm, unactivated platelets, circulating in peripheral blood, are biconvex disco- 
id (lens-shaped) structures, whereas the surface of activated ones is covered with cell membrane projections (Michelson, 2013). Platelets maintain hemostasis, regulate inflammation and are involved in innate and adaptive immune response (Gaertner \& Massberg, 2016; Hampton, 2018). Thrombocytes contain several types of granules $(\alpha-, \delta$ - (dense granules), $\gamma-, \lambda$-), the content of which secrete to the exterior in the process of activation. Platelets are considered as "scanning soldiers" of the immune system, reacting to the presence of bacteria invading the bloodstream, interacting with lymphocytes, and regulating extravasation in part of immune cell (Labelle et al., 2014; Best at al., 2018).

Platelets and their derivatives have a key role in the regulation of homeostasis and tissue repair processes due to the ability of releasing from $\alpha$-granules low molecular weight peptides and proteins, which are involved in intracellular signaling and recruiting of immune, progenitor mesenchymal cells in regulatory regeneration cascades (Cole et al., 2010; Stellos et al., 2010; Sundman et al., 2011). Among these proteins are growth factors, cytokines and chemokines (Stellos et al., 2010; Huong et al., 2019), in particular, platelet-derived growth factor (PDGF), transforming growth factor (TGF)- $\beta$, platelet-derived epidermal growth factor (PDEGF), vascular endothelial growth factor (VEGF), insulin-like growth factor (IGF)-1, fibroblast growth factor (FGF) and epidermal growth factor (EGF). The indicated factors (PDGF, TGF- $\beta$, IGF, VEGF, bFGF, EGF) induce DNA synthesis and mitotic division, stimulate cell growth, chemotaxis and angiogenesis, enhance cell proliferation and migration, activate the synthesis of intercellular matrix, collagen and glycosaminoglycans, and play an essential role in processes of physiological healing. In addition, antibacterial, fungicidal proteins, proteases (metalloprotease-4) and coagulation system factors are detected in platelets. Except for $\alpha$-granules, platelets contain $\delta$-(dense) granules that store and emit after activation ADP, ATP, histamine, serotonin, dopamine and calcium ions, as well as lysosomal $(\gamma-)$ granules that can secrete acidic hydrolases, cathepsin D, E, elastase, lysozyme, which provide biochemical and metabolic processes in the organism, including inflammatory and regenerative responses (Sharda \& Flaumenhaft, 2018).

Platelets and their agents play an important role in the progression and active spread of the tumour, promoting the activation of angiogenic factors and neovascularization (Lana et al., 2017; Best et al., 2018; Huong et al., 2019). By releasing through their membranes microvesicles the tumour cells transmit mutant RNAs to platelets, which absorb and transport them in vivo and in vitro (Nilsson et al., 2011). Platelets can infiltrate in tumour tissue (Pucci et al., 2016). Platelets of patients with glioma contain tumour-associated RNA EGFRvIII and PCA3, and differ in the RNA profile from platelets of healthy subjects, which may have a diagnostic and prognostic value. Since platelets accumulate tumour-secreted membrane microvesicles with tumour-associated RNA, they potentially can serve as a source of this biomarker for tumour diagnosis. In addition to the absorption of microvesicles, platelets can actively and efficiently release pro-tumour microvesicles, contributing to the spread of tumorous RNA by the circulatory system, which probably provides a "strategy" for the tumour survival (Nilsson et al., 2011).

Platelets have a key role in the development of pathological tumour angiogenesis. The content of protein-regulators of angiogenesis in platelets selectively increases with the presence of a tumour and can be used for early detection of a tumour or its progression (Cervi et al., 2008; Klement et al., 2009). Released platelet secretion products from patients with glioblastoma show a strong pro-angiogenic effect on glioblastomaderived endothelial cells (Di Vito et al., 2016). ADP and thrombin stimulation leads to a significant increase in the level of VEGF platelet secretion (pro-agiogenic factor), but not endostatin (an angiogenesis inhibitor), as compared to healthy subjects. Intraplatelet concentrations of VEGF have also been significantly increased in patients with glioblastoma. A direct correlation between the levels of platelet-released VEGF and the overall survival time of these patients was found (Di Vito et al., 2016). The accumulation in the platelets of experimental animals with malignant tumours of molecules-regulators of blood vessel formation (VEGF, PDGF, bFGF) significantly exceeds their concentration in the platelets of animals without cancer pathology and proves the presence of tumours in vivo at an early stage. At the same time, platelets do not absorb proportional amounts of other plasma proteins (eg, albumin) even in the presence of high concentrations. Thus, platelets have a selective ability to absorb proteins - regulators of angiogenesis in tumour carriers that can be used for diagnostics and monitoring the effectiveness of targeted antiangiogenic treatment (Klement et al., 2009).

The data above show the significant pathogenetic role of cellular growth factors that regulate the processes of proliferation in tumours, including the tumours of the central nervous system. In this regard, the study of the properties of platelets in patients with brain glioma is particularly promising, because these cells are the source of numerous cytokines, chemokines, growth factors as well as tumour-associated RNA.

The experimental rat glioma C6 is similar to glioblastoma and recognized as commonly used in neurooncology as the model of tumour process. C6 glioma cells contain P-glycoprotein, CD133-prominin (marker protein of tumour stem cells), anti-apoptotic factors and while cultivated form "spherical" clusters (Schraen-Maschke \& Zanetta, 2003) multilayered ordered cellular conglomerates of round form.

The objective of the study was investigation of the effect of secreted platelet factors in patients with brain glioma (platelet-released secretion products - PRSP) on experimental glioma C6, mitotic activity and formation of cellular clusters in vitro.

\section{Materials and methods}

The study used the glioma cells of line C6 (provided by Cell Lines Bank from Human and Animal Tissues, R. E. Kavetsky Institute of Experimental Pathology, Oncology and Radiobiology, National Academy of Sciences of Ukraine, Kyiv), as well as peripheral blood and biopsy material of patients, who were surveyed and treated at the State Institution Romodanov Neurosurgery Institute, National Academy of Medical Sciences of Ukraine (SI INS NAMS): patients with neurooncology ( $\mathrm{n}=$ 12) and persons without rough somatic pathology (comparison group, $n$ $=6$ ). The tumour diagnoses were verified with histological examination: 6 cases of diffuse astrocytoma (second degree of malignancy $\mathrm{G} 2$ ) and 6 glioblastomas (fourth degree of malignancy - G4) according to the latest edition of the WHO classification of tumours of the nervous system (Louis et al., 2016). The study was performed within the framework of the research project (State registration number 0117U004271 (2017-2019) in accordance with the protocol approved by the Bioethics Committee of SI INS NAMS (protocol No. 3 dated 06.06.2016).

Platelets were isolated from peripheral blood of patients $(5.0 \mathrm{~mL})$ by differential centrifugation (Frimel, 1987). The cell concentration was adjusted with a buffered saline solution to $110^{9} / \mathrm{mL}$ and cells were passed through a microbiological filter PES $(\mathrm{d}=0.2 \mu \mathrm{m}$, MDI, India), thus obtaining medium containing PRSP. Modified media with PRSP were added to the C6 experimental glioma cell cultures. In order to compare, in parallel experiments, the conditioned media of peripheral blood cells (CMPBC) of patients were added to $\mathrm{C} 6$ glioma cell cultures.

To obtain CMPBC, $0.5 \mathrm{~mL}$ of peripheral blood of patients was added to $1.5 \mathrm{~mL}$ of the nutrient medium 199 (BioTestlab, Ukraine) with gentamicin $(0.16 \mathrm{mg} / \mathrm{mL})$ and mitogens $(0.04 \mathrm{mg} / \mathrm{mL}$ phytohaemagglutinin, $0.04 \mathrm{mg} / \mathrm{mL}$ concanavalin $\mathrm{A}, 0.02 \mathrm{mg} / \mathrm{mL}$ lipopolysaccharide, Pan Eko Ltd, RF) and incubated for 24 hours in a thermostat at $37^{\circ} \mathrm{C}$. Further, the cells were precipitated by centrifugation for 5 minutes at $1500 \mathrm{rpm}$, washed in a medium 199, $1.5 \mathrm{~mL}$ of fresh medium 199 was added to sediment cells and incubated for 48 hours in the thermostat at $37^{\circ} \mathrm{C}$. After that, the cells were precipitated by centrifugation for $5 \mathrm{mi}-$ nutes at $1500 \mathrm{rpm}$, and CMPBC (supernatant) was selected.

For control cultures, $110^{6}$ were suspended in a RPMI nutrient medium (Biowest, France) with 10\% fetal calf serum (Biowest, France), glucose $(400 \mathrm{mg} \%)$, insulin $(0.05 \mathrm{mg} / \mathrm{mL})$, transferrin $(0.0275 \mathrm{mg} / \mathrm{mL})$, selenite $\left(0.0275 \mathrm{mg} / \mathrm{mL}\right.$, Pan Eko Ltd, RF). For experimental cultures, $110^{6}$ were suspended in a nutrient medium with the addition of PRSP (in the ratio of 1:10) or addition of CMPBC of patients. Control and experimental cell suspensions were transferred to cover glasses, pre-coated with polyethyleneimine (Sigma-Aldrich, $\mathrm{GmbH}$, Germany) into sterile plastic Petri dishes. Accordingly, experimental groups of C6 glioma cell cultures were formed, which were cultured under the following conditions: 1) standard nutrient medium (control) and addition of: 2) PRSP of patients with glioma G4; 3) PRSP of patients with glioma G2; 4) PRSP 
of patients without oncopathology; 5) CMPBC of patients with glioma G4; 6) CMPBC of patients with glioma G2; 7) CMPBC of patients without oncopathology.

The cultures were kept in a $\mathrm{CO}_{2}$-incubator (Nuve, Turkey). Dynamic observation with microphotography was performed on an inverted microscope Nikon S-100 (Japan).

After 72 hours of incubation, cell cultures were fixed in $10 \%$ neutral formalin (Bio-Optica, Italy) and stained with hematoxylin-eosin. Microscopic examination and photoregistration of histological and cytological preparations of cultures was carried out on a light-optical photomicroscope NIKON Eclipse E200 (Japan).

In each preparation, the structural features of the experimental cultures were compared with the control ones. The cell composition of the growth zone of glioma cultures was evaluated according to tumour cells' morphological characteristics and their ability to form spatial histotypical structures, peculiar to neuroglial growth in tissue culture. The form of cytoplasmic bodies of tumour cells, the presence and branching of processes, the structure and character of the chromatin distribution and the form of nuclei, and the features of intercellular interactions were analyzed. In the surviving areas of the growth zone, the changes in mitotic activity were determined. The mitotic index (MI) was calculated as the proportion of cells with the presence of mitoses from the total amount of cells in \%. The quantity of mitoses, as well as the number of formed clusters (multilayered, ordered, round-shaped cell conglomerates) was determined for each sample on the test area (in 10 randomly selected fields of view of the microscope $\left({ }^{\mathrm{x}} 400\right)$.

Statistical data processing was performed using statistical software package Statistica 8.0 (StatSoft Inc., USA). Nonparametric methods of variation statistics were used (Kruskal-Wallis test for multiple comparison of independent groups). Data in tables are presented as $\mathrm{x} \pm \mathrm{SE}$ (mean \pm standard error of the mean). Statistically significant differences were considered at $\mathrm{P}<0.05$.

\section{Results}

Characteristics of C6 glioma cell cultures (control observations). In the first 24 hours after explantation, the observation revealed formation of round-shaped cell clusters, from which tumour cells without distinct signs of differentiation (with a narrow cytoplasm and moderate nucleus polymorphism) actively migrated around.

Between these thickened cell conglomerates, monolayer growth areas of cells of astrocytic structure with sprouts were observed (Fig. 1a). After 72 hours of cultivation in control cultures a significant increase in the growth and stratification of cellular microaggregates was observed, with predominance of tumour cells of the astrocytic structure of the unipolar, triangular, rhomboid, polygonal form with elongated processes that formed reticular structure (Fig. $1 b, c$ ).

In areas of accretion of undifferentiated tumour cells MI was on average $2.74 \pm 0.17 \%$ (Table 1). Pathological forms of mitoses were found, mainly at the metaphase stage. In particular, we determined the hollow metaphases (Fig. 2a); lagging of chromosomes and their fragments in the metaphase (Fig. 2b); K-mitosis with conglutination of chromosomes (Fig. 2c); asymmetric mitosis with lagging chromosomes (Fig. 2g); as well as sticky forms of the mitotic plate, mitosis with chromosomal scattering, three-pole, multipole mitosis, formation of "bridges". According to the calculation of formed multilayered ordered roundshaped cell conglomerates, their number was on average $8.70 \pm 0.99$ on the test area in the obtained histological preparations of C6 glioma cell culture samples (Table 2).

Characteristics of experimental C6 glioma cell cultures under the influence of PRSP. C6 glioma cell cultures cultivated in a medium with the addition of PRSP of patients with glioma G4 from the first hours of cultivation were characterized by active growth with the formation of spherical cell conglomerates, from which tumour cells migrated unevenly radially. Between conglomerates, formation of reticular growth zones was observed, consisting of cells of polygonal form with long branched sprouts (Fig. 3a). Extension of the cultivation period to 72 hours showed further active growth of cultures, which was accompanied by filling the entire area of cultivating field with monolayer accretion of tu- mour cells with areas of reticular form (Fig. 3b). Mean values of MI as well as the number of formed multilayer cell clusters exceeded the corresponding indicators of control cultures by 1.2 times (Table 1,2).

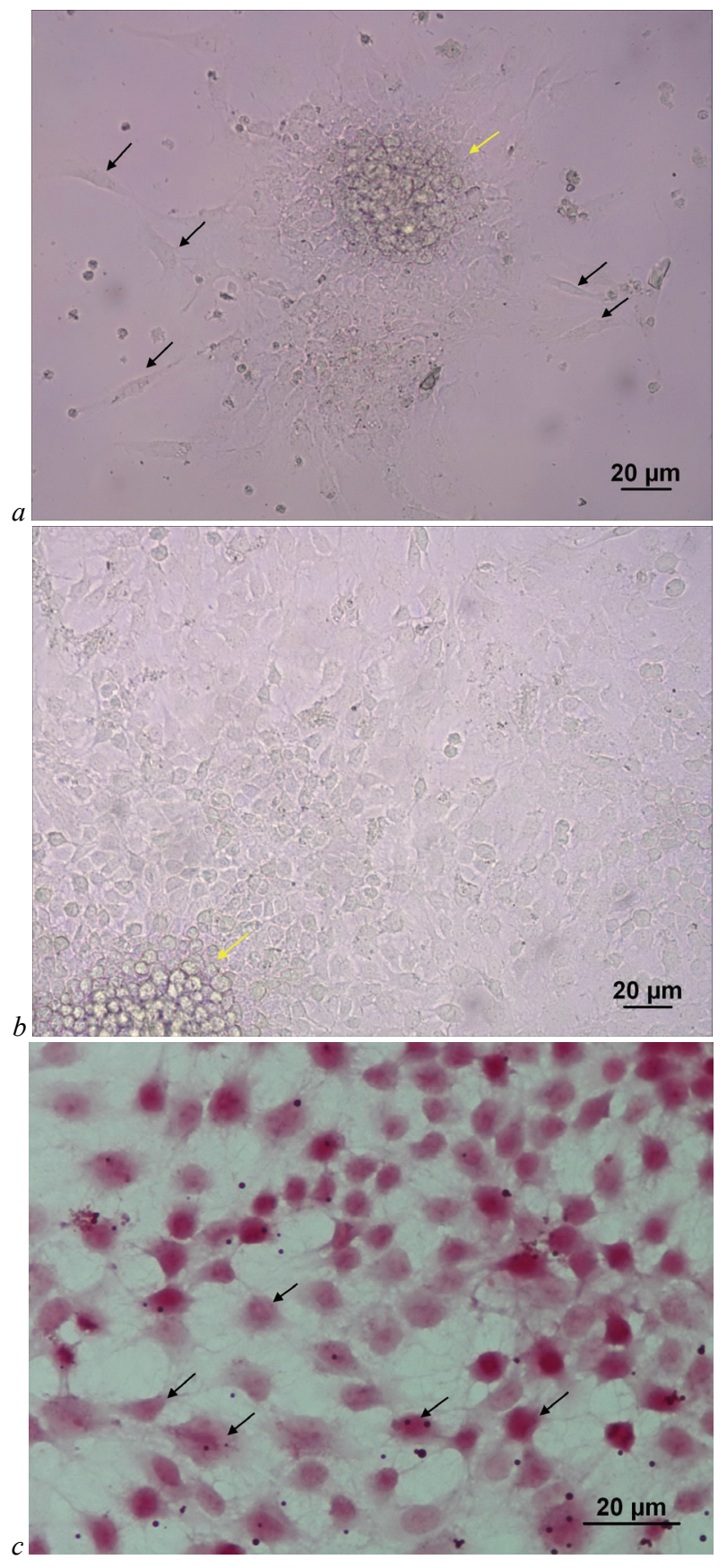

Fig. 1. Microphotos of C6 glioma cell cultures (control, light microscopy): $a$-native culture, 24 hours of cultivation, dense-cell growth area formed by tumour cells migrating from a cell cluster; $b$-native culture, 72 hours of cultivation, dense-cell growth area with the transition to the reticular structure; $c-72$ hours of cultivation, hematoxylin-eosin staining, expressed polymorphism of tumour cells forming the reticular zone of growth, yellow arrow round-shaped cell cluster; black arrow - migrating tumour cells of astrocytic structure with sprouts

Observation of $\mathrm{C} 6$ glioma cell cultures, cultivated in a medium with the addition of PRSP of patients with glioma G2, after 24 hours revealed less active growth of the culture (Fig. $3 c$ ). Although in the course of further cultivation the growth zone of these experimental cultures approached control indices by structure and set of cellular elements (Fig. 3d), the MI value in this experimental group was the smallest -1.5 times less than the control culture index and 1.8 times lower than the culture index under the 
influence of PRSP of patients with glioma G4 (Table 1). Under the influence of PRSP of patients with glioma G2, in experimental glioma C6 cultures the smallest number of cell clusters was formed - 1.1 times less than in the control, and 1.3 times less than the culture index under the influence of PRSP of patients with glioma G4 (Table 2).

Observation of C6 glioma cell cultures, cultivated under the conditions of adding PRSP of persons of the comparison group revealed similar features to the previous experimental groups: the shaping of cellular rounded complexes and the formation of a dense monolayer of tumour cells with well-developed bodies and branched sprouts (Fig. $3 e, f$ ). At the same time, the MI value and the quantity of formed cell clusters in the cultures of this experimental group did not differ from the control indicators (Table 1,2).

\section{Table 1}

Change in mitotic index (\%) in C6 glioma cell cultures under the influence of modified media containing platelet-released secretion products or conditioned media of peripheral blood cells of patients with glioma ( $x \pm S E, n=6,72$ hours of cultivation)

\begin{tabular}{|c|c|c|}
\hline Groups & Mitotic index, $\%$ & $\mathrm{P}$ (Kruskal-Wallis test) \\
\hline Control & $2.74 \pm 0.17^{\mathrm{add}}$ & $\begin{array}{c}{ }^{\mathrm{a}}-\mathrm{P}=2 \cdot 10^{-4} \\
\mathrm{c}^{\mathrm{c}}-\mathrm{P}=8 \cdot 10^{-4} \\
\mathrm{~d}-\mathrm{P}=0.01\end{array}$ \\
\hline \multicolumn{3}{|c|}{ Modified media with platelet-released secretion products (PRSP) } \\
\hline - patients with glioma G4 & $3.39 \pm 0.20^{\mathrm{f}}$ & $\mathrm{f}-\mathrm{P}=8 \cdot 10^{-5}$ \\
\hline - patients with glioma G2 & $1.84 \pm 0.17^{\mathrm{ab}}$ & $\begin{array}{l}\text { a }-P=2 \cdot 10^{4}, \\
{ }^{b}-P=8 \cdot 10^{-5}\end{array}$ \\
\hline - persons of the comparison group & $2.80 \pm 0.17^{\mathrm{b}}$ & ${ }^{b}-\mathrm{P}=8 \cdot 10^{-5}$ \\
\hline \multicolumn{3}{|c|}{ Conditioned media of peripheral blood cells (CMPBC) } \\
\hline - patients with glioma G4 & $1.83 \pm 0.14^{\mathrm{cef}}$ & $\begin{array}{c}{ }^{\mathrm{c}}-\mathrm{P}=8 \cdot 10^{4} \\
\mathrm{e}-\mathrm{P}=0.05 \\
\mathrm{f}-\mathrm{P}=8 \cdot 10^{-5}\end{array}$ \\
\hline - patients with glioma G2 & $2.04 \pm 0.17^{\mathrm{d}}$ & ${ }^{d}-P=0.01$ \\
\hline - persons of the comparison group & $2.53 \pm 0.17^{\mathrm{e}}$ & $\mathrm{e}-\mathrm{P}=0.05$ \\
\hline
\end{tabular}

\section{Table 2}

Change in the number of formed cell clusters in C6 glioma cell cultures under the influence of modified media containing platelet-released secretion products or conditioned media of peripheral blood cells of patients with glioma $(\mathrm{x} \pm \mathrm{SE}, \mathrm{n}=6,72$ hours of cultivation)

\begin{tabular}{lcc}
\hline \multicolumn{1}{c}{ Groups } & $\begin{array}{c}\text { Number } \\
\text { of clusters }\end{array}$ & $\mathrm{P}$ (Kruskal-Wallis test) \\
\hline \multicolumn{1}{c}{ Control } & $8.70 \pm 0.99$ & $\mathrm{P}>0.05$ \\
\hline \multicolumn{2}{l}{ Modified media with platelet-released secretion products (PRSP) } \\
\hline - patients with glioma G4 & $10.30 \pm 0.42^{\mathrm{ab}}$ & ${ }^{\mathrm{a}}-\mathrm{P}=0.003,{ }^{\mathrm{b}}-\mathrm{P}=0.03$ \\
- patients with glioma G2 & $7.75 \pm 0.58^{\mathrm{a}}$ & ${ }^{\mathrm{a}}-\mathrm{P}=0.003$ \\
- persons of the comparison group & $8.35 \pm 0.50^{\mathrm{b}}$ & ${ }^{\mathrm{b}}-\mathrm{P}=0.03$ \\
\hline Conditioned media of peripheral blood cells $(\mathrm{CMPBC})$ & \\
\hline - patients with glioma G4 & $8.15 \pm 0.87$ & $\mathrm{P}>0.05$ \\
- patients with glioma G2 & $7.70 \pm 1.06$ & $\mathrm{P}>0.05$ \\
- persons of the comparison group & $8.00 \pm 0.59$ & $\mathrm{P}>0.05$ \\
\hline
\end{tabular}

Characteristics of experimental C6 glioma cell cultures under the influence of CMPBC. In the first 3 hours of cultivation, no differences were observed in the growth rates of experimental cultures compared with the control ones: cells of the experimental glioma C6 formed clusters from which the cells migrated, forming a growth zone (Fig. $4 a, b, c$ ).

During the next 72 hours of cultivation under the influence of CMPBC of patients with glioma G4, CMPBC of patients with glioma $\mathrm{G} 2$ as well as $\mathrm{CMPBC}$ of persons of the comparison group, the structure and density of the $\mathrm{C} 6$ glioma cell growth region were similar to control cultures (Fig. 5). However, the mitotic activity of the cells in the experimental groups differed (Table 1): under the influence of CMPBC of patients with glioblastoma (G4) and diffuse astrocytoma (G2) it decreased (respectively, 1.5 and 1.3 times, as compared to control), whereas the addition of CMPBC of persons of the comparison group to the nutrient medium of cultured C6 glioma cells did not cause significant changes in the number of cells in the mitotic state (at the same time, differing from the indicator under the influence of CMPBC of patients with glioblastoma (G4), exceeding the last one by 1.4 times). The MI index in the experimental C6 glioma cell cultures under the influence of the CMPBC of patients with glioblastoma (G4) was 1.85 times smaller than the MI value in the cultures under the influence of the PRSP of these patients (Table 1).
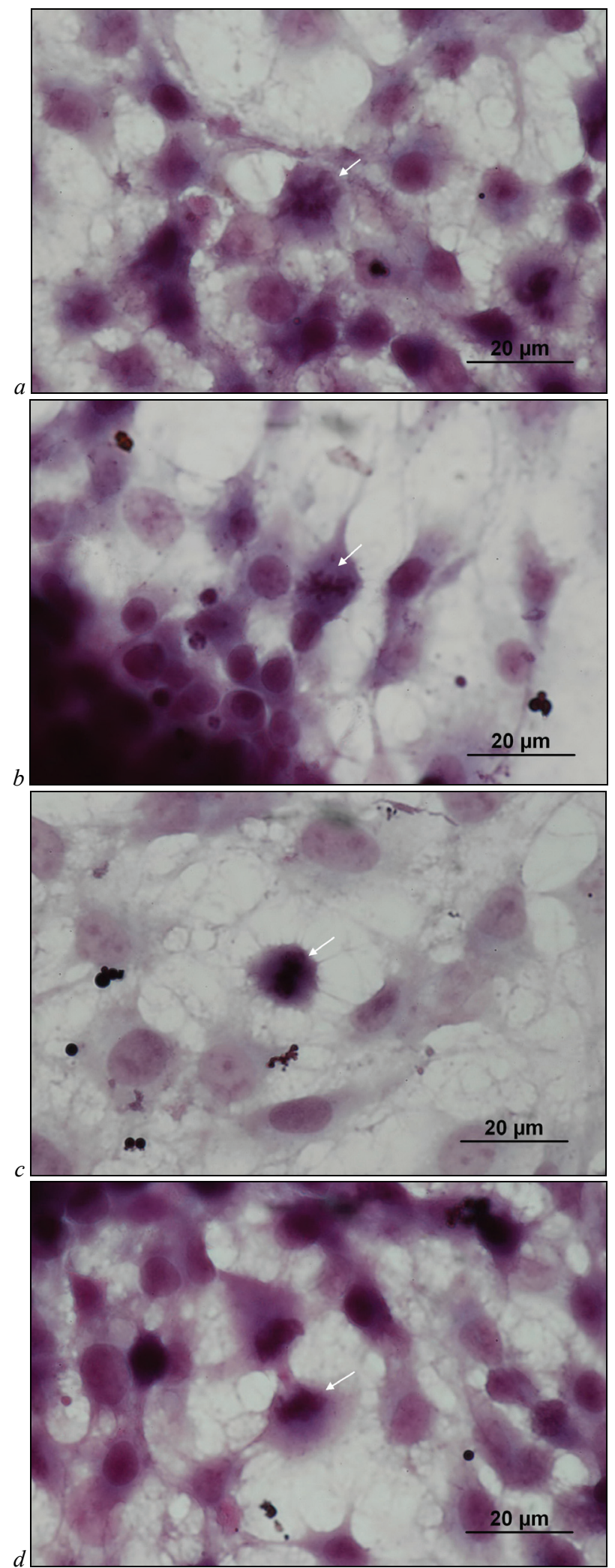

Fig. 2. Microphotos of C6 glioma cell cultures (control,

light microscopy, hematoxylin-eosin staining): the forms of pathological mitosis (white arrows); $a$ - hollow metaphase; $b$ - lagging of chromosomes and their fragments in the metaphase; $c$-K-mitosis with conglutination of chromosomes; $d$-asymmetric mitosis with lagging chromosomes 

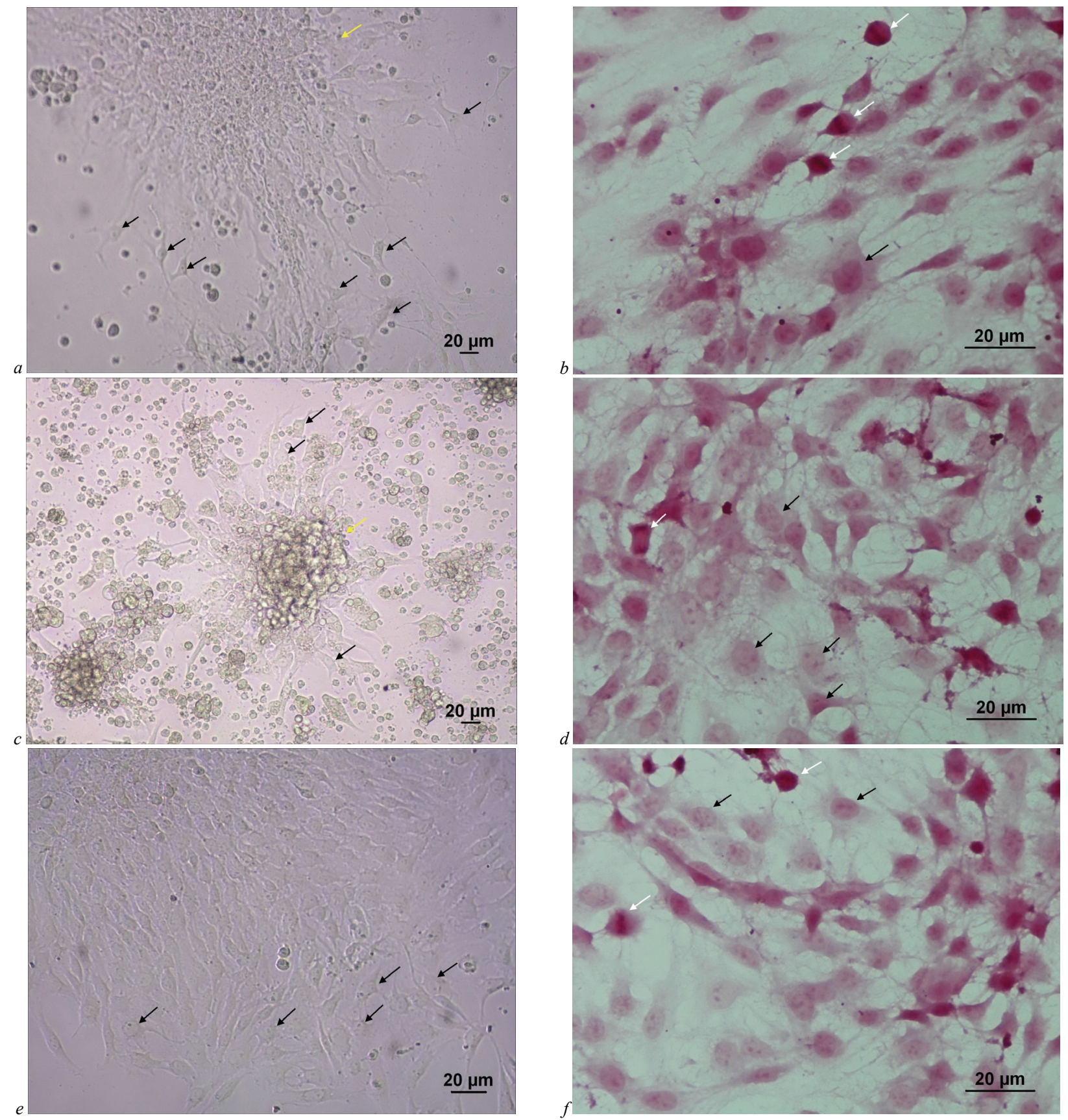

Fig. 3. Microphotos of C6 glioma cell cultures: morphological changes of cells under the influence of platelet-released secretion products (PRSP) of patients with gliomas of different degree of malignancy; light microscopy; $a, b$-culture of C6 glioma cells after addition of PRSP of patients with glioma G4, 72 hours, in-vitro observation $(a)$ and hematoxylin-eosin staining $(b)$, forming of growth zone by tumour cells of astrocytic structure with sprouts; $c, d$-culture of C6 glioma cells after addition of PRSP of patients with glioma G2, in-vitro observation $(c, 24$ hours, cell cluster with migrating tumour cells) and hematoxylin-eosin staining ( $d, 72$ hours, expressed polymorphism and mitotic activity of tumour cells in formed monolayer growth zone of reticular structure); $e, f$-culture of $\mathrm{C} 6$ glioma cells after addition of PRSP of persons of the comparison group, 72 hours, in-vitro observation ( $e$, active migration of cells from spread cluster) and hematoxylin-eosin staining $(f$, polymorphism and mitotic activity of tumour cells in formed monolayer growth zone of reticular structure); yellow arrow -

round-shaped cell cluster; black arrow - tumour cells of astrocytic structure with sprouts; white arrow - cells in the stage of mitosis

The addition of CMPBC of patients with glioma G4, as well as $\mathrm{CMPBC}$ of patients with glioma $\mathrm{G} 2$ or CMPBC of persons of the comparison group did not significantly affect the number of formed cell clusters in the C6 glioma cell cultures after 72 hours of cultivation (Table 2). At the same time, the number of formed cell clusters under the influence of CMPBC of patients with glioblastoma (G4) was 1.26 times less than the corresponding index in experimental cultures under the influence of PRSP of these patients (Table 2). Thus, summing up the results of the performed studies, we can conclude that the overall structure of the growth zone of the C6 experimental glioma after a 72-hour period of influence of PRSP and CMPBC of neurooncological patients predominantly does not show changes in comparison with control cultures. The cell composition and density of the formed growth zones in experimental cultures are similar to the control ones; in cultures cell clusters are formed by the type of "spheroids", from which migration of cells takes place, a dense cellular or reticular growth zone is formed. During 72 hours of observation no cytotoxic effects of the studied biological factors were noted. In tumour cells of experimental cultures the ability to mitotic division remains.

Simultaneously due to the influence of the investigated factors of PRSP and CMPBC of neurooncological patients in C6 glioma cell cultures quantitative changes in mitotic activity and activity of the formation of "spheroidal" cell clusters were determined depending on the biological factors of different populations of peripheral blood cells of patients with gliomas and depending on the degree of tumour malignancy. 

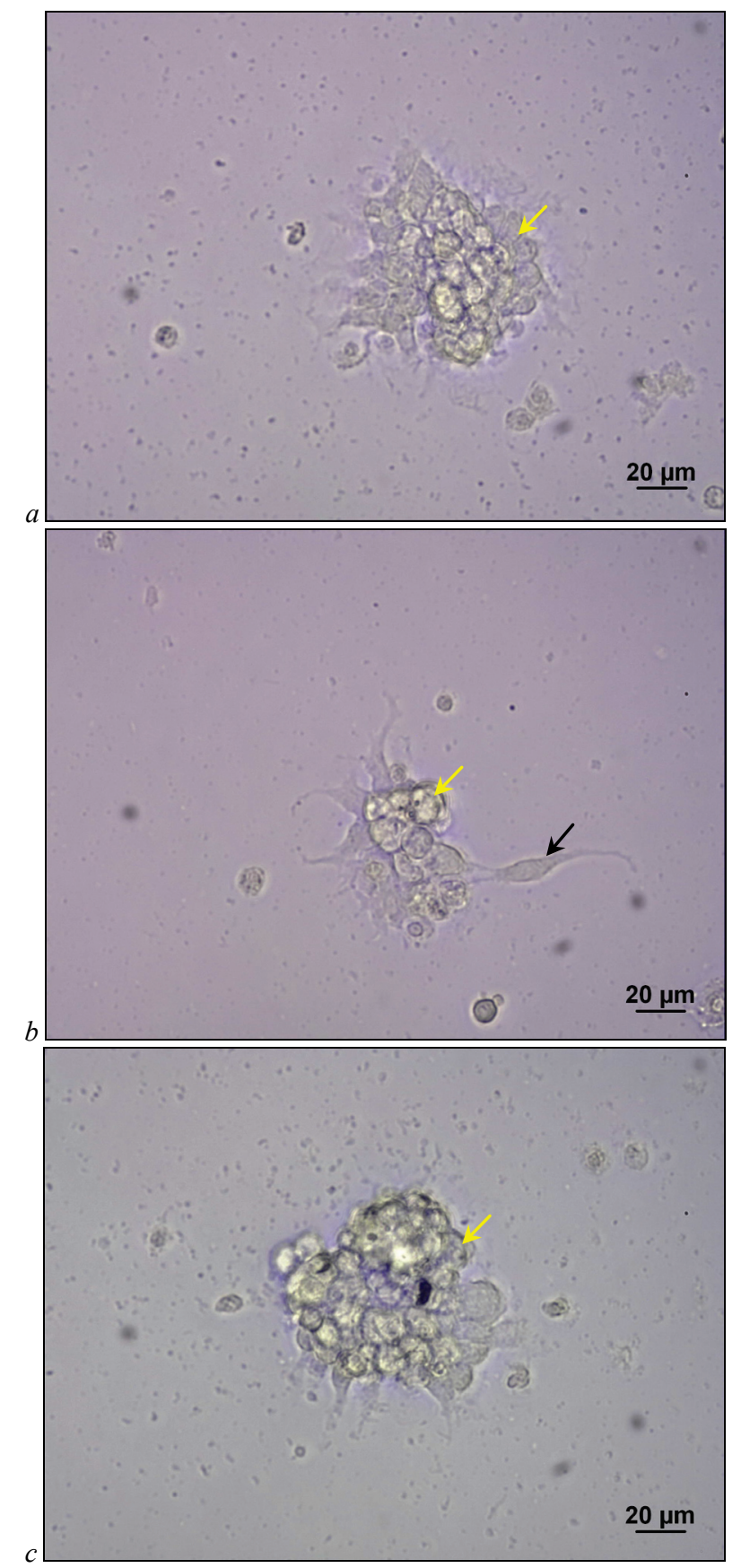

Fig. 4. Microphotos of C6 glioma cell cultures (light microscopy, in-vitro observation; 3 hours of cultivation after addition of conditioned media of peripheral blood cells (CMPBC) of patients): $a-\mathrm{CMPBC}$ of patients with glioma G4; $b-\mathrm{CMPBC}$ of patients with glioma $\mathrm{G} 2 ; c-\mathrm{CMPBC}$ of persons of the comparison group, yellow arrow - round-shaped cell cluster, black arrow - migrating tumour cell

\section{Discussion}

In our study, the cells of experimental glioma C6 were used to reproduce the malignant tumour growth pattern of the brain glioma in vitro, which, when cultured, formed reticular growth zones characteristic of neuroglial cells, retained the ability to mitotic division and formed cellular clusters of round form ("spheroids"). Among the cultured C6 glioma cells pathological forms of mitoses occured, which is inherent in malignant variants of the brain gliomas. The pathology of mitosis implies proliferation through the chromosomal separation patterns that are not eliminated by the mechanism of apoptosis. It is known that with the growth of malignancy of the tumour, the frequency of mitosis pathology rises and the variety of its pathological forms increases (Kraevskij et al., 1984). Thus, the frequency of mitosis pathology grows from $5-10 \%$ in low-grade dysplasia to $60 \%$ and $80 \%$ respectively in high-grade dysplasia and cancer (Steinbeck, 2001). We observed pathological mitoses at the stage of metaphase that is due to fragmentation of the chromosomes and damage of the mitotic apparatus: hollow metaphases, which arise due to incorrect location or damage to chromosomal threads; lagging of the chromosomes and their fragments in the metaphase; delay and blockade of mitosis in the metaphase (K-mitosis) with the adherence of chromosomes, leading to the destruction of the nucleus and the death of the cell; asymmetric mitosis with lagging chromosomes, the result of which is the uneven distribution of chromosomes in the ana-telophase and the formation of aneuploid daughter cells; as well as sticky forms of the mitotic plate, mitosis with chromosomal scattering, three-pole, multi-polar mitosis, the formation of "bridges", which indicates an increase in cellular aneuploidy and is one of the signs of malignancy (Kraevskij et al., 1984, Steinbeck, 2001).

The formation of cellular clusters of rounded form ("spheroids", "neurospheres", "tumorospheres") when cultivating C6 glioma cells may also be considered as a sign of malignant tumour growth. The formation of spheroidal derivations in the growth dynamics in culture is believed to be the fundamental property of brain tumour stem cells (BTSC), which determines the initiation and proliferation of tumours in brain tissue (Laks et al., 2009) and is similar to the NSC/NPCs property to form the "neurospheres". It should be noted that the similarity of characteristics between the glioma cells and NSCs: a similar phenotype, proteome, secretome, comparable profile of receptor expression, adhesion molecules and identical targets of migration (Nakano, 2015; Yamamuro et al., 2015; Song et al., 2016; Amodeo et al., 2017; Garcia et al., 2017; Mehta \& Lo Cascio, 2017; Qin et al., 2017) - is assumed as phylogenetic and it is suggested that brain tumours are derived from NSC/NPCs undergoing aberrant changes, BTSCs (Kusne \& Sanai, 2015; Stangeland et al., 2015; Zong et al., 2015; Ledur et al., 2016; Okawa et al., 2017). The content of BTSCs in glioma tissue enlarges proportionally with an increase in their malignancy, which is accompanied by raised expression levels of immunocytochemical markers of their stem phenotype (Bao et al., 2014; Wang et al., 2014).

It is known that tumours of low degree of malignancy, in particular highly differentiated, are not always able to form "tumorospheres" (Gunther et al., 2008; Panosyan et al., 2010). It is believed that the ability to form a "tumorospheres" reflects the high tumorigenicity of the BTSCs with an unfavourable prognosis (Panosyan et al., 2010). At the same time, the generation of spheroidal formations may be the result of adhesion, aggregation of cells. Thus, according to research (Kool et al., 2012), all studied tumours (both with favourable and unfavourable prognosis) at the initial stage of cultivation formed spheres in cultures with high cell density, but it was impossible to consistently passage the spheres derived from tumours associated with a favourable prognosis (astrocytomas, ependymomas, beta-catenin-activated medulloblastomas), and the initial formation of spheres was probably due to cell adhesion rather than the ability to form "neurospheres". Obtaining the "neurospheres" for a long time was considered a gold standard for maintaining the population of tumorigenic cells of the primary tumour, but adherent cultures of brain tumour cells also support tumorigenic properties during cultivation in a serum-free medium (Pollard et al., 2009; Persson et al., 2010), providing cells with a more uniform access to growth factors. In a comparative study of these two methodological approaches for obtaining BTSCs of malignant gliomas in adhesive culture and in form of "tumorospheres" (Rahman et al., 2015), the functional equivalence of both approaches is proved.

In our study for the cultivation of C6 glioma cells, adhesion conditions were used - seeding on the cover glasses with polyethyleneimine, with the addition of $10 \%$ fetal calf serum to the nutrient medium, which gave the cells the capability to attach to the substrate and differentiate. In such conditions we observed signs of differentiation in the astrocytic direction with the formation of distinct processes and reticular structures. At the same time, cells in culture had the capacity to form multicellular "spheroid" clusters and retain their mitotic activity. We consider these characteristics as confirmation of the signs of malignancy of the experimental C6 glioma, and their quantitative changes after the addition of the studied modified and conditioned media of cells of peripheral blood of patients we observed as criteria for the presence of influence of biological factors contained in the appropriate media. 

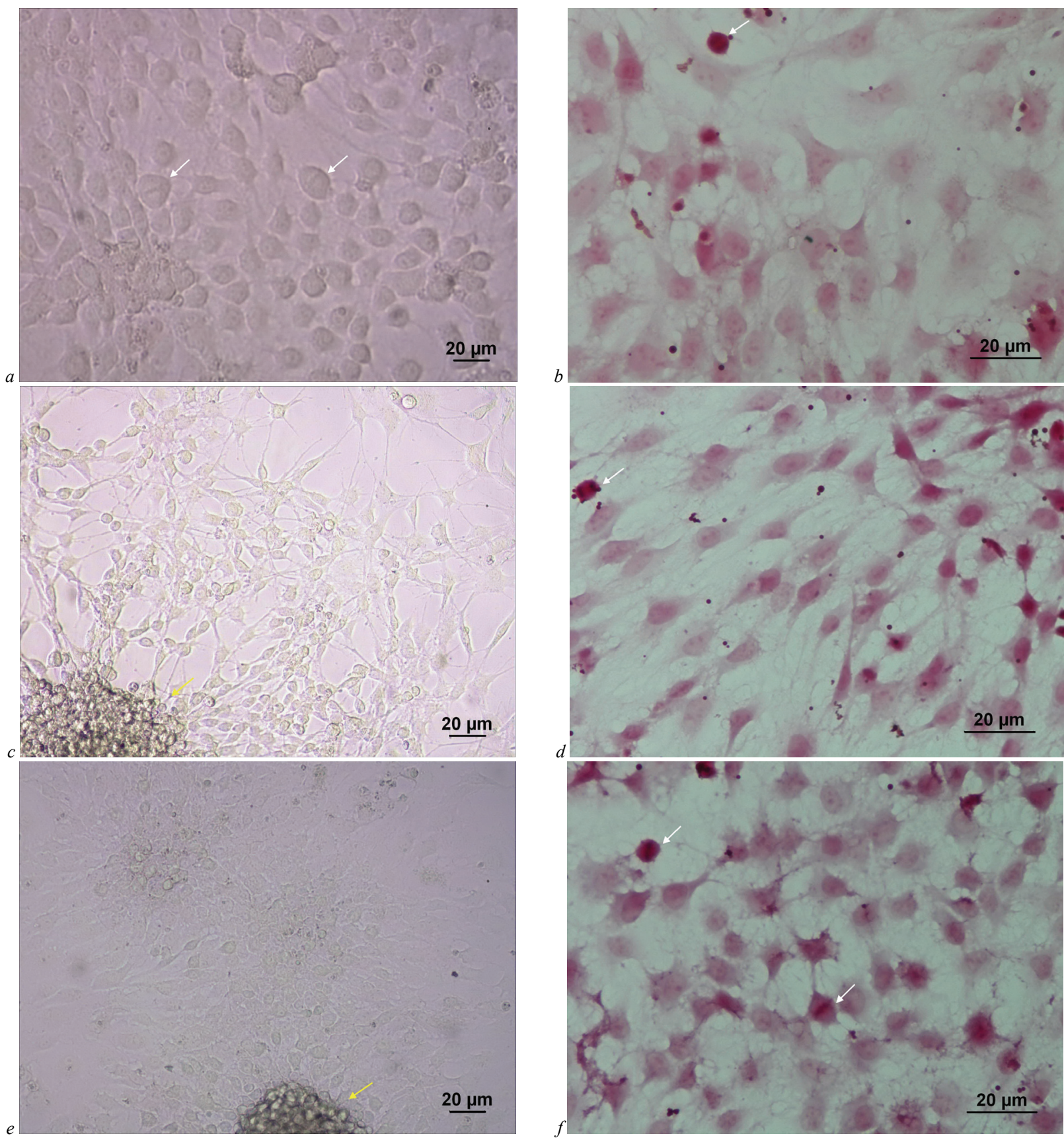

Fig. 5. Microphotos of C6 glioma cell cultures: morphological characteristics of cells under the influence of conditioned media of peripheral blood cells (CMPBC) of patients with gliomas of different degree of malignancy; light microscopy, 72 hours of cultivation, reticular growth zone of polymorphic tumour cells of astrocytic structure with branched sprouts: $a$-in-vitro observation after adding CMPBC of patients with glioma $\mathrm{G} 4 ; b$ - culture preraration after adding CMPBC of patients with glioma $\mathrm{G} 4$, hematoxylin-eosin staining; $c$-in-vitro observation after adding $\mathrm{CMPBC}$ of patients with glioma $\mathrm{G} 2 ; d$ - culture preraration after adding CMPBC of patients with glioma $\mathrm{G} 2$, hematoxylin-eosin staining; $e$-in-vitro observation after adding CMPBC of persons of the comparison group; $f$-culture preparation after adding CMPBC of persons of the comparison group, hematoxylin-eosin staining; yellow arrow - round-shaped cell cluster; white arrow - cells in the stage of mitosis

We discovered the dependence of the effects of modified media obtained from different populations of peripheral blood cells of patients with gliomas on the source of such media, as well as on the degree of tumour malignancy.

The study established that the effects of PRSP of patients with gliomas differ depending on the degree of tumor malignancy: PRSP of patients with glioblastomas (high-grade glioma G4) stimulate mitotic activity and the formation of cell clusters in C6 glioma cell cultures and PRSP of patients with diffuse astrocytoma (glioma G2) - suppress. At the same time, CMPBC, obtained from the general pool of cells of peripheral blood of patients after mitogen induction, inhibit the mitotic activity of $\mathrm{C} 6$ glioma cells and do not affect the formation of cell clusters. Important, in our opinion, is the fundamental difference in the effects of modified media of various populations of peripheral blood cells of patients with malignant glioma (G4) - stimulation by PRSP and inhibition by CMPBC. Indicators of mitotic activity and the quantity of formed cell clusters in the culture of $\mathrm{C} 6$ glioma cells under the influence of PRSP of patients with malignant glioma exceeded the indices obtained under the influence of CMPBC of these patients. We believe that PRSP and CMPBC can be considered as a source of various substances produced by these cells that reproduce the microenvironment of these cells in the organism, and given the circulation of these cells in the bloodstream - their modified and conditioned media can also be considered as a source of systemic influence of these cells due to paracrine effects of soluble mediators. The obtained data on the effects of PRSP and CMPBC of patients with gliomas of various degrees of malignancy indicate the secretion by these cells of biologically active molecules (cytokines, growth factors, DNA, RNA, etc.) capable of regulating the 
cell cycle and proliferative activity of tumour cells of the C6 glioma. Moreover, the principal difference in the effects of modified and conditioned media is due, apparently, to the difference in the spectrum of secreted biologically active molecules released by thrombocytes of peripheral blood of patients with brain glioma depending on the degree of tumour malignancy or produced by a pool of peripheral blood cells in response to stimulation of mitogens.

Since CMPBC were obtained from a general pool of peripheral blood cells of patients (including leukocytes, platelets, red blood cells) after induction by mitogens - concanavalin A, phytohemagglutinin (stimulating proliferation mainly of T-lymphocytes) and lipopolysaccharide (acts as an endotoxin, binds to the receptor complex CD14/TLR4/MD2, which causes secretion of proinflammatory cytokines in many cell types, especially in macrophages), it can be assumed that these CMPBC include a large number of cytokines of proinflammatory direction. Obviously, the content of these cytokines (probably interleukin (IL)-1, tumour necrosis factor (TNF)- $\alpha$, interferon (IFN)- $\gamma$, IL-12, IL-18 etc.) may explain the inhibition of the mitotic activity of tumour cells of cultured C6 glioma under the influence of CMPBC of patients with gliomas, in particular, high-grade gliomas (G4).

This fact is promising and can be taken into account in the development of new approaches to enhancing the effectiveness of the immune response in patients with gliomas, namely, stimulation of the effector function of immunocytes after influence of mitogens, in order to intensify the homing, immune recognition and immune killing of tumour cells. The use of mitogens with the purpose of strengthening the effector antitumour function of the immunocytes (T-, NK-cells) is generally embedded in the common concept of approaches to adaptive immunotherapy, which are now actively being developed and related, in particular, the immunological checkpoint blockade (blocking of inhibitory molecules on T cells, such as CTLA-4 and PD1), genetic engineering of immune cells (T-, NK-cells) with CARs; systemic administration of cytokines (Klingemann et al., 2016; Veluchamy et al., 2017; Matosevic, 2018).

In contrast to the CMPBC, the PRSP of patients with gliomas obviously has in its composition another spectrum of biologically active substances, which is significantly different in its effects in the culture of C6 glioma cells depending on the degree of tumour malignancy. In particular, based on scientific literature data in recent years, it can be assumed that PRSP of patients with gliomas contain such growth factors as PDGF, TGF- $\beta$, IGF, VEGF, EGF, bFGF, and tumour-associated RNAs. The listed growth factors are known as mitogens, regulators of basic cell processes such as proliferation, differentiation, survival / or apoptosis, that induce DNA synthesis and mitotic division, stimulate cell growth (Cole et al., 2010). In addition, as shown in patients with glioma and animals with malignant tumours, platelets absorb and transport tumour associated mutant RNAs and pro-angiogenic, pro-tumour growth factors (Cervi et al., 2008; Klement et al., 2009; Di Vito et al., 2016).

On the basis of the data obtained, it can be assumed that the multidirectional effects of the secreted factors of platelets of patients with gliomas of various degrees of malignancy, namely the capability to regulate the cell cycle and inhibit (platelets of patients with glioma G2) or stimulate (platelets of patients with glioma G4) proliferative activity of tumour cells of experimental C6 glioma are linked, firstly, to the ability of the platelets to absorb and accumulate tumour mutant RNAs. The platelet RNA's content is apparently a reflection of the tumourassociated RNA profile in gliomas (Loo et al., 2019). Thus, it has been shown that in $80 \%$ of patients with glioblastomas, tumours of which were positive for mutant EGFRvIII, mutations were also found in platelets (Nilsson et al., 2011). Moreover, the potential of thrombocytes in patients with gliomas as a non-invasive biomarker source for the creation of marker RNAs panels is studied. Platelets are characterized as tumour-educated blood platelets (TEPs), and one can obtain specific information on the presence, localization and molecular characteristics of the tumours based on the content and profile of their RNAs (Best et al., 2018). Thrombocytes from patients with tumours, in particular, brain tumours, differ from cells of patients with inflammatory and other non-tumour diseases (Best et al., 2018), which is consistent with our data, since we have not detected the effects of the influence of PRSP of patients without neurooncological pathology unlike the PRSP of patients with gliomas.

Secondly, the content of growth factors in platelets, obviously, depends on the degree of malignancy of the tumour. It is known that the degree of glioma malignancy correlates with the number and palette of molecular-genetic changes in expression of genes with pro-tumour characteristics. In particular, the course of malignant gliomas is accompanied by activation of the PDGF signaling pathways and over-expression of the PDGF-B ligand (Zheng et al., 2016). In the presence of glioblastoma in platelets, the internal content and level of secretion of proteins regulators of angiogenesis such as VEGF, PDGF, bFGF increase (Cervi et al., 2008; Klement et al., 2009; Di Vito et al., 2016), thus platelets create a favourable environment for neovascularization and maintenance of tumour growth and stimulate the expression of these growth factors. Also, TGF- $\beta$ is an important agent of malignant phenotype of human brain gliomas (Frei et al., 2015), since its expression rises to a large extent in highly malignant gliomas (Kaminska et al., 2013; Dubrovska \& Souchelnytskyi, 2014). TGF- $\beta$ has a dual role: it is a potent inhibitor of proliferation of epithelial cell and astrocytes, and is considered a tumour suppressing factor in the early stages of tumour growth (Mints \& Souchelnytskyi, 2014; Frei et al., 2015), but in its later stages, when the switching of cells for the utilization of TGF- $\beta$ happens, it potentially acts as a promoter of cellular mobility, invasion, metastasis, and support of BTSCs (Dubrovska \& Souchelnytskyi, 2014). During carcinogenesis, as a consequence of mutations in the component parts of the canonical TGF- $\beta$ signaling pathway, in malignant gliomas a switch takes place from the TGF- $\beta$ Smad-dependent signaling pathway to Smadindependent ones (Frei et al., 2015). The first pathway is linked with antiproliferative and tumour-suppressive TGF- $\beta$ effects, and other pathways are engaged in pro-tumour TGF- $\beta$ action and prevent the TGF- $\beta$ antiproliferative effect, facilitating in this way its promoter action (Frei et al., 2015). Thrombocytes reduce apoptosis and can provoke epithelial-mesenchymal transition of tumour cells by releasing TGF- $\beta$ (Labelle et al., 2011, 2014; Haemmerle et al., 2017).

The difference in the effects of biologically active factors that are released by platelets and other peripheral blood cells of patients with high-grade glioma variants (G4) indicate the important role of platelets in the pathogenesis of these tumours. This is consistent with the data about correlation between the high preoperative level of the platelet-tolymphocyte ratio and the poor prognosis in patients with glioma (Bao et al., 2018), and vice versa, correlation of low platelet levels with the term of overall survival of patients with temozolomide therapy (Saito et al., 2018). During platelet activation, numerous growth and pro-angiogenic factors are released, creating a metastatic niche - a microenvironment that stimulates tumour growth (Klement et al., 2009; McAllister \& Weinberg, 2014).

Interesting in this regard is a study (Panek et al., 2018) which shows that activated platelets can release a soluble CD40 ligand (sCD40L), which is a significant inhibitor of T-regulatory lymphocytes with immunosuppressive functions. The authors found that local implantation of the platelet-rich fibrin plaster (PRF-P) in the brain of mice with glioma GL261 prolonged the survival of experimental mice by more than $40 \%$, which was accompanied by a decrease in the number of intratumour lymphocytes, predominantly T-regulatory lymphocytes. The co-culture of GL261 glioma cells or chemoattractants (CCL2/22) with PRF-P discontinued the migration of T-regulatory lymphocytes, and the blockade of CCL2/22 interaction with receptors by pharmacological agents enhanced this effect. It is also believed that platelets are involved in the regulation of local and distant "cross-talk" between glioma cells and glioma-associated microglia/macrophages and myeloid suppressor cells through numerous soluble proteins and cell-surface-binding factors for the creation of an immunosuppressive niche for tumour expansion (Wurdinger et al., 2014). Thrombocytes affect resident tumour cells and those that enter the bloodstream, forming cell-fibrin-platelet aggregates protecting circulating tumour cells and transmitting them the MHC class I proteins, further protecting against the recognition of natural killer cells (Jiang et al., 2017).

Thus, PRSP is a fundamental component of the microenvironment and an important aspect of the biology of the tumour involved in the 
processes of tumour initiation and progression and can serve as a diagnostic and predictive marker of response to antitumour therapy.

\section{Conclusion}

On the model of experimental malignant glioma in vitro - cultured cells of glioma C6, various-directed effects of released thrombocyte secretion products in patients with glioma were established, depending on the degree of tumour malignancy: stimulation of cell mitotic activity and formation of cell clusters in cultures under the influence of platelet factors of patients with glioma G4 and inhibition - under the influence of platelet factors of patients with glioma $\mathrm{G} 2$.

Multidirectional effects of secreted factors of different populations of peripheral blood cells of patients with glioma G4 have been determined: in contrast to the secretion products released by platelets which stimulate mitotic activity and the formation of cell clusters in C6 glioma cell cultures, conditioned media obtained after mitogenic stimulation of a general pool of peripheral blood cells suppress the mitotic activity of tumour cells and do not affect the number of "spheroid" clusters.

The obtained results indicate the important role of platelets in the pathogenesis of the brain gliomas and substantiate the expediency of further in-depth study and clinical-morphological comparison.

\section{References}

Amodeo, V., Betts, J., Bartesaghi, S., Zhang, Y., Richard-Londt, A., Ellis, M., Roshani, R., Vouri, M., Galavotti, S., Oberndorfer, S., Leite, A. P., Mackay, A., Lampada, A., Stratford, E. W., Li, N., Dinsdale, D., Grimwade, D., Jones, C., Nicotera, P., Michod, D., Brandner, S., \& Salomoni, P. (2017). A PML/Slit axis controls physiological cell migration and cancer invasion in the CNS. Cell Reports, 20(2), 411-426.

Bao, B., Ali, S., Ahmad, A., Li, Y., Banerjee, S., Kong, D., Aboukameel, A., Mohammad, R., Van Buren, E., Azmi, A. S., \& Sarkar, F. H. (2014). Differentially expressed miRNAs in cancer-stem-like cells: markers for tumor cell aggressiveness of pancreatic cancer. Stem Cells and Development, 23(16), 1947-1958.

Bao, Y., Yang, M., Jin, C., Hou, S., Shi, B., Shi, J., \& Lin, N. (2018). Preoperative hematologic inflammatory markers as prognostic factors in patients with glioma. World Neurosurgery, 119, e710-e716.

Best, M. G., Wesseling, P., \& Wurdinger, T. (2018). Tumor-educated platelets as a noninvasive biomarker source for cancer detection and progression monitoring. Cancer Research, 78(13), 3407-3412.

Cervi, D., Yip, T., Bhattacharya, N., Podust, V. N., Peterson, J., Abou-Slaybi, A., Naumov, G. N., Bender, E., Almog, N., Italiano, J. E., Folkman, J., \& Klement, G. L. (2008). Platelet-associated PF-4 as a biomarker of early tumor growth. Blood, 111(3), 1201-1207.

Chambers, A. M., Lupo, K. B., \& Matosevic, S. (2018). Tumor microenvironmentinduced immunometabolic reprogramming of natural killer cells. Frontiers in Immunology, 9, 2517.

Cole, B. J., Seroyer, S. T., Filardo, G., Bajaj, S., \& Fortier, L. A. (2010). Plateletrich plasma: Where are we now and where are we going? Sports Health, 2(3), 203-210

Di Vito, C., Navone, S. E., Marfia, G., Abdel Hadi, L., Mancuso, M. E., Pecci, A., Crisà, F. M., Berno, V., Rampini, P., Campanella, R., \& Riboni, L. (2016). Platelets from glioblastoma patients promote angiogenesis of tumor endothelial cells and exhibit increased VEGF content and release. Platelets, 29, 1-10.

Dubrovska, A. M., \& Souchelnytskyi, S. S. (2014). Low-density microarray analysis of TGF-1-dependent cell cycle regulation in human breast adenocarcinoma MCG7 cell line. Biopolymers and Cell, 30(2), 107-117.

Fedorenko, Z. P., Michailovich, Y. Y., Goulak, L. O., Gorokh, Y. L., Ryzhov, A. Y., Soumkina, O. V., \& Koutsenko, L. B. (2019). Cancer in Ukraine, 2017-2018. Incidence, mortality, activities of oncological service. Bulletin of National Cancer Registry of Ukraine, 20, 56-57.

Frei, K., Gramatzki, D., Tritschler, I., Schroeder, J. J., Espinoza, L., Rushing, E. J., $\&$ Weller, M. (2015). Transforming growth factor- $\beta$ pathway activity in glioblastoma. Oncotarget, 6(8), 5963-5977.

Frimel, G. (Ed.). (1987). Immunologicheskie metody [Immunological methods]. Medicina, Moscow (in Russian).

Gaertner, F., \& Massberg, S. (2016). Blood coagulation in immunothrombosis at the frontline of intravascular immunity. Seminars in Immunology, 28(6), 561-569.

Garcia, I., Aldaregia, J., Marjanovic Vicentic, J., Aldaz, P., Moreno-Cugnon, L., Torres-Bayona, S., Carrasco-Garcia, E., Garros-Regulez, L., Egaña, L., Rubio, A., Pollard, S., Stevanovic, M., Sampron, N., \& Matheu, A. (2017). Oncogenic activity of SOX1 in glioblastoma. Scientific Reports, 7, 46575.
Gunther, H. S., Schmidt, N. O., Phillips, H. S., Kemming, D., Kharbanda, S., Soriano, R., Modrusan, Z., Meissner, H., Westphal, M., \& Lamszus, K. (2008). Glioblastoma-derived stem cell-enriched cultures form distinct subgroups according to molecular and phenotypic criteria. Oncogene, 27, 2897-2909.

Gutova, M., Flores, L., Adhikarla, V., Tsaturyan, L., Tirughana, R., Aramburo, S., Metz, M., Gonzaga, J., Annala, A., Synold, T. W., Portnow, J., Rockne, R. C., \& Aboody, K. S. (2019). Quantitative evaluation of intraventricular delivery of therapeutic neural stem cells to orthotopic glioma. Frontiers in Oncology, 9, 68.

Haemmerle, M., Taylor, M. L., Gutschner, T., Pradeep, S., Cho, M. S., Sheng, J., Lyons, Y. M., Nagaraja, A. S., Dood, R. L., Wen, Y., Mangala, L. S., Hansen, J. M., Rupaimoole, R., Gharpure, K. M., Rodriguez-Aguayo, C., Yim, S. Y., Lee, J.-S., Ivan, C., Hu, W., Lopez-Berestein, G., Wong, S. T., Karlan, B. Y., Levine, D. A., Liu, J., Afshar-Kharghan, V., \& Sood, A. K. (2017). Platelets reduce anoikis and promote metastasis by activating YAP1 signaling. Nature Communications, $8,310$.

Hampton, T. (2018). Platelets' role in adaptive immunity may contribute to sepsis and shock. Journal of the American Medical Association, 319(13), 1311-1312.

Huong, P. T., Nguyen, L. T., Nguyen, X. B., Lee, S. K., \& Bach, D. H. (2019). The role of platelets in the tumor-microenvironment and the drug resistance of cancer cells. Cancers (Basel), 11(2), e240.

Jiang, X., Wong, K. H. K., Khankhel, A. H., Zeinali, M., Reategui, E., Phillips, M. J., Luo, X., Aceto, N., Fachin, F., Hoang, A. N., Kim, W., Jensen, A. E., Sequist L. V., Maheswaran, S., Haber, D. A., Stott, S. L., \& Toner, M. (2017). Microfluidic isolation of platelet-covered circulating tumor cells. Lab on a Chip, 17, 3498-3453.

Kaminska, B., Kocyk, M., \& Kijewska, M. (2013). TGF beta signaling and its role in glioma pathogenesis. Advances in Experimental Medicine and Biology, 986, 171-187.

Kaya, V., Yildirim, M., Yazici, G., Yalçin, A. Y., Orhan, N., \& Güzel, A. (2017). Prognostic signifiance of indicators of systemic inflammatory responses in glioblastoma patients. Asian Pacific Journal of Cancer Prevention, 18(12), 3287-3291.

Klement, G. L., Yip, T. T., Cassiola, F., Kikuchi, L., Cervi, D., Podust, V., Italiano, J. E., Wheatley, E., Abou-Slaybi, A., Bender, E., Almog, N., Kieran, M. W., \& Folkman, J. (2009). Platelets actively sequester angiogenesis regulators. Blood, 113(12), 2835-2842.

Klingemann, H., Boissel, L., \& Toneguzzo, F. (2016). Natural killer cells for immunotherapy - advantages of the NK-92 cell line over blood NK cells. Frontiers in Immunology, 7, 91.

Kool, M., Korshunov, A., Remke, M., Jones, D. T. W., Schlanstein, M., Northcott, P. A., Cho, Y.-J., Koster, J., Schouten-van Meeteren, A., van Vuurden, D., Clifford, S. C., Pietsch, T., von Bueren, A. O., Rutkowski, S., McCabe, M., Collins, V. P., Bäcklund, M. L., Haberler, C., Bourdeaut, F., Delattre, O., Doz, F., Ellison, D. W., Gilbertson, R. J., Pomeroy, S. L., Taylor, M. D., Lichter, P., \& Pfister, S. M. (2012). Molecular subgroups of medulloblastoma: An international meta-analysis of transcriptome, genetic aberrations, and clinical data of WNT, SHH, Group 3, and Group 4 medulloblastomas. Acta Neuropathologica, 123 , 473-484.

Kraevskij, N. I., Kazanceva, I. A., Ol'hovskaja, I. G., \& Probatova, N. A. (1984). Issledovanie patologii mitoza $\mathrm{v}$ klinicheskoj onkomorfologii [The study of the pathology of mitosis in clinical oncomorphology]. Arhiv Patologii, 11, 16-22.

Kusne, Y., \& Sanai, N. (2015). The SVZ and its relationship to stem cell based neuro-oncogenesis. Advances in Experimental Medicine and Biology, 853, 23-32.

Labelle, M., Begum, S., \& Hynes, R. O. (2011). Direct signaling between platelets and cancer cells induces an epithelial-mesenchymal-like transition and promotes metastasis. Cancer Cell, 20, 576-590.

Labelle, M., Begum, S., \& Hynes, R. O. (2014). Platelets guide the formation of early metastatic niches. Proceedings of the National Academy of Sciences of the United States of America, 111, e3053-e3061.

Laks, D. R., Masterman-Smith, M., Visnyei, K., Angenieux, B., Orozco, N. M., Foran, I., Yong, W. H., Vinters, H. V., Liau, L. M., Lazareff, J. A., Mischel, P. S., Cloughesy, T. F., Horvath, S., \& Kornblum, H. I. (2009). Neurosphere formation is an independent predictor of clinical outcome in malignant glioma. Stem Cells, 27, 980-987.

Lana, J. F. S. D., Purita, J., Paulus, C., Huber, S. C., Rodrigues, B. L., Rodrigues, A. A. Santana, M. H., Madureira, J. L. Jr., Malheiros Luzo, Â. C., Belangero, W. D., \& Annichino-Bizzacchi, J. M. (2017). Contributions for classification of platelet rich plasma - proposal of a new classification: Marspill. Regenerative Medicine, 12(5), $565-574$.

Ledur, P. F., Liu, C., He, H., Harris, A. R., Minussi, D. C., Zhou, H. Y., Shaffrey, M. E., Asthagiri, A., Lopes, M. B., Schiff, D., Lu, Y. C., Mandell, J. W., Lenz G., \& Zong, H. (2016). Culture conditions tailored to the cell of origin are critical for maintaining native properties and tumorigenicity of glioma cells. NeuroOncology, 18(10), 1413-1424.

Li, M., Sun, S., Dangelmajer, S., Zhang, Q., Wang, J., Hu, F., Dong, F., Kahlert, U. D., Zhu, M., \& Lei, T. (2019). Exploiting tumor-intrinsic signals to induce 
mesenchymal stem cell-mediated suicide gene therapy to fight malignant glioma. Stem Cell Research and Therapy, 10(1), 88.

Loo, H. K., Mathen, P., Lee, J., \& Camphausen, K. (2019). Circulating biomarkers for high-grade glioma. Biomarkers in Medicine, 3(3), 161-165.

Lopes, M., Carvalho, B., Vaz, R., \& Linhares, P. (2018). Influence of neutrophillymphocyte ratio in prognosis of glioblastoma multiforme. Journal of NeuroOncology, 136(1), 173-180.

Louis, D. N., Ohgaki, H., Wiestler, O. D., \& Cavenee, W. K. (2016). WHO classification of tumours of the central nervous system. WHO Classification of Tumours. 4th edition, IARC.

Machlus, K. R., Thon, J. N., \& Italiano, J. E. (2014). Interpreting the developmental dance of the megakaryocyte: A review of the cellular and molecular processes mediating platelet formation. British Journal of Haematology, 165(2), 227-236.

Matosevic, S. (2018). Viral and nonviral engineering of natural killer cells as emerging adoptive cancer immunotherapies. Journal of Immunology Research, 2018, 4054815 .

McAllister, S. S., \& Weinberg, R. A. (2014). The tumour-induced systemic environment as a critical regulator of cancer progression and metastasis. Nature Cell Biology, 16, 717-727.

Mehta, S., \& Lo Cascio, C. (2018). Developmentally regulated signaling pathways in glioma invasion. Cellular and Molecular Life Sciences, 75(3), 385- 402.

Michelson, A. D. (Ed.). (2013). Platelets. 3rd ed. Academic Press, Oxford.

Mints, M., \& Souchelnytskyi, S. (2014). Impact of combinations of EGF, TGF, 17-oestradiol, and inhibitors of corresponding pathways on prolipheration of breast cancer cell lines. Experimental Oncology, 36(2), 67-71

Mooney, R., Hammad, M., Batalla-Covello, J., Abdul Majid, A., \& Aboody, K. S. (2018). Concise review: Neural stem cell-mediated targeted cancer therapies. Stem Cells Translational Medicine, 7(10), 740-747.

Nakano, I. (2015). Stem cell signature in glioblastoma: Therapeutic development for a moving target. Journal of Neurosurgery, 122(2), 324-330

Nilsson, R. J., Balaj, L., Hulleman, E., van Rijn, S., Pegtel, D. M., Walraven, M. Widmark, A., Gerritsen, W. R., Verheul, H. M., Vandertop, W. P., Noske, D. P. Skog, J., \& Wurdinger, T. (2011). Blood platelets contain tumor-derived RNA biomarkers. Blood, 118(13), 3680-3683.

Okawa, S., Gagrica, S., Blin, C., Ender, C., Pollard, S. M., \& Krijgsveld, J. (2017) Proteome and secretome characterization of glioblastoma-derived neural stem cells. Stem Cells, 35(4), 967-980.

Panek, W. K., Pituch, K. C., Miska, J., Kim, J. W., Rashidi, A., Kanojia, D., Lopez-Rosas, A., Han, Y., Yu, D., Chang, C. L., Kane, J. R., Zhang, P., Cordero, A., \& Lesniak, M. S. (2018). Local application of autologous platelet-rich fibrin patch (PRF-P) suppresses regulatory $\mathrm{T}$ cell recruitment in a murine glioma model. Molecular Neurobiology, 2018, 1-9.

Panosyan, E. H., Laks, D. R., Masterman-Smith, M., Mottahedeh, J., Yong, W. H. Cloughesy, T. F., Lazareff, J. A., Mischel, P. S., Moore, T. B., \& Kornblum, H. I. (2010). Clinical outcome in pediatric glial and embryonal brain tumors correlates with in vitro multi-passageable neurosphere formation. Pediatric Blood and Cancer, 55, 644-651.

Persson, A. I., Petritsch, C., Swartling, F. J., Itsara, M., Sim, F. J., Auvergne, R. Goldenberg, D. D., Vandenberg, S. R., Nguyen, K. N., Yakovenko, S., AyersRingler, J., Nishiyama, A., Stallcup, W. B., Berger, M. S., Bergers, G., McKnight, T. R., Goldman, S. A., \& Weiss, W. A. (2010). Non-stem cell origin for oligodendroglioma. Cancer Cell, 18(6), 669-682.

Poggi, A., \& Giuliani, M. (2016). Mesenchymal stromal cells can regulate the immune response in the tumor microenvironment. Vaccines, 4, 41

Pollard, S. M., Yoshikawa, K., Clarke, I. D., Danovi, D., Stricker, S., Russell, R., Bayani, J., Head, R., Lee, M., Bernstein, M., Squire, J. A., Smith, A., \& Dirks, P. (2009). Glioma stem cell lines expanded in adherent culture have tumor-specific phenotypes and are suitable for chemical and genetic screens. Cell Stem Cell, 4(6), 568-580.

Portnow, J., Synold, T. W., Badie, B., Tirughana, R., Lacey, S. F., D'Apuzzo, M., Metz, M. Z., Najbauer, J., Bedell, V., Vo, T., Gutova, M., Frankel, P., Chen, M., \& Aboody, K. S. (2017). Neural stem cell-based anticancer gene therapy: A first-in-human study in recurrent high-grade glioma patients. Clinical Cancer Research, 23(12), 2951-2960.

Pucci, F., Rickelt, S., Newton, A. P., Garris, C., Nunes, E., Evavold, C., Pfirschke, C., Engblom, C., Mino-Kenudson, M., Hynes, R. O., Weissleder, R., \& Pittet, M. J. (2016). PF4 promotes platelet production and lung cancer growth. Cell Reports, 17(7), 1764-1772.
Qin, E. Y., Cooper, D. D., Abbott, K. L., Lennon, J., Nagaraja, S., Mackay, A., Jones, C., Vogel, H., Jackson, P. K., \& Monje, M. (2017). Neural precursor-derived pleiotrophin mediates subventricular zone invasion by glioma. Cell, 170(5), 845-859.

Rahman, M., Reyner, K., Deleyrolle, L., Millette, S., Azari, H., Day, B. W., Stringer, B. W., Boyd, A. W., Johns, T. G., Blot, V., Duggal, R., \& Reynolds, B. A. (2015). Neurosphere and adherent culture conditions are equivalent for malignant glioma stem cell lines. Anatomy and Cell Biology, 48(1), 25-35.

Saito, T., Sugiyama, K., Hama, S., Yamasaki, F., Takayasu, T., Nosaka, R., Muragaki, Y., Kawamata, T., \& Kurisu, K. (2018). Prognostic importance of temozolomide-induced neutropenia in glioblastoma, IDH-wildtype patients. Neurosurgical Review, 41(2), 621-628.

Schraen-Maschke, S., \& Zanetta, J. P. (2003). Role of oligomannozidic N-glycans in the proliferation, adhesion of $\mathrm{C}_{6}$ glioblastoma cells and signaling. Biochimie, $85(1-2), 219-229$.

Sharda, A., \& Flaumenhaft, R. (2018). The life cycle of platelet granules. F1000Research, 7, 236.

Song, W. S., Yang, Y. P., Huang, C. S., Lu, K. H., Liu, W. H., Wu, W. W, Lee, Y. Y., Lo, W. L., Lee, S. D., Chen, Y. W., Huang, P. I., \& Chen, M. T. (2016) Sox2, a stemness gene, regulates tumor-initiating and drug-resistant properties in CD133-positive glioblastoma stem cells. Journal of the Chinese Medical Association, 79(10), 538-545.

Stangeland, B., Mughal, A. A., Grieg, Z., Sandberg, C. J., Joel, M., Nygård, S., Meling, T., Murrell, W., Vik Mo, E. O., \& Langmoen, I. A. (2015). Combined expressional analysis, bioinformatics and targeted proteomics identify new potential therapeutic targets in glioblastoma stem cells. Oncotarget, 6(28), $26192-26215$

Steinbeck, R. G. (2001). Pathologic mitoses and pathology of mitosis in tumorigenesis. European Journal of Histochemistry, 45, 311-318.

Stellos, K., Kopf, S., Paul, A., Marquardt, J. U., Gawaz, M., Huard, J., \& Langer, H. F. (2010). Platelets in regeneration. Seminars in Thrombosis and Hemostasis, 36, 175-184.

Sundman, E. A., Cole, B. J., \& Fortier, L. A. (2011). Growth factor and catabolic cytokine concentrations are influenced by the cellular composition of platelet-rich plasma. American Journal of Sports Medicine, 39(10), 2135-2140.

van Linde, M. E., van der Mijn, J. C., Pham, T. V., Knol, J. C., Wedekind, L. E. Hovinga, K. E., Aliaga, E. S., Buter, J., Jimenez, C. R., Reijneveld, J. C., \& Verheul, H. M. (2016). Evaluation of potential circulating biomarkers for prediction of response to chemoradiation in patients with glioblastoma. Journal of Neuro-Oncology, 129(2), 221-230.

Veluchamy J. P., Kok, N., van der Vliet, H. J., Verheul, H. M. W., de Gruijl, T. D., \& Spanholtz, J. (2017). The rise of allogeneic natural killer cells as a platform for cancer immunotherapy: recent innovations and future developments. Frontiers in Immunology, 8, 631.

Wang, X., Ren, H., Zhao T., Chen, J., Sun, W., Sun, Y., Ma, W., Wang, J., Gao, C., Gao, S., Lang, M., Jia, L., \& Hao, J. (2014). Stem cell factor is a novel independent prognostic biomarker for hepatocellular carcinoma after curative resection. Carcinogenesis, 35(10), 2283-2290.

Wurdinger, T., Deumelandt, K., van der Vliet, H. J., Wesseling, P., \& de Gruijl, T. D. (2014). Mechanisms of intimate and long-distance cross-talk between glioma and myeloid cells: how to break a vicious cycle. Biochimica et Biophysica Acta, 1846(2), 560-575.

Yamamuro, S., Okamoto, Y., Sano, E., Ochiai, Y., Ogino, A. Ohta, T., Hara, H., Ueda, T., Nakayama, T., Yoshino, A., \& Katayama, Y. (2015). Characterization of glioma stem-like cells from human glioblastomas. International Journal of Oncology, 47(1), 91-96.

Zhang, J., Yang, W., Zhao, D., Han, Y., Liu, B., Zhao, H., Wang, H., Zhang, Q. \& Xu, G. (2013). Correlation between TSP-1, TGF- $\beta$ and PPAR- $\gamma$ expression levels and glioma microvascular density. Oncology Letters, 7(1), 95-100.

Zheng, Y., Yamamoto, S., Ishii, Y., Sang, Y., Hamashima, T., Van De, N., Nishizono, H., Inoue, R., Mori, H., \& Sasahara, M. (2016). Glioma-derived plateletderived growth factor-BB recruits oligodendrocyte progenitor cells via plateletderived growth factor receptor- $\alpha$ and remodels cancer stroma. The American Journal of Pathology, 186(5), 1081-1091.

Zong, H., Parada, L. F., \& Baker, S. J. (2015). Cell of origin for malignant gliomas and its implication in therapeutic development. Cold Spring Harbor Perspectives in Biology, 7(5), a020610. 